\title{
A New HPLC Method for Analysis of Natural Monacolin K in Red Yeast Rice Pharmaceutical Preparations
}

\section{Sabry OMM*}

Pharmacognosy Department-Faculty of Pharmacy, Cairo University, Cairo-11562, Egypt

\begin{abstract}
Monacolin K (lovastatin or mevinolin) is a naturally occurring hypocholesterolemic statin used to prevent cardiovascular diseases for those persons suffering from hypercholesterolemia, a condition characterized by very high levels of cholesterol in the blood. It is originally derived from the fungus Monascus ruber and Monascus purpureus family Monascaceae. Monacolin $\mathrm{K}$ is a lactone polyketide derived compound converted in the body to the active form, B-hydroxy acid of monacolin K. It acts by inhibiting the hepatic HMG-CoA Reductase enzyme. In this paper, we report a selective precise and accurate new HPLC method for analysis of both lactone form and acid form of monacolin $\mathrm{k}$ in red rice pharmaceutical preparations.
\end{abstract}

Keywords: Red yeast rice; Monascus purpureus; Monacolin K; Lovastatin; HPLC; Diode array detector (DAD)

\section{Introduction}

Red yeast rice is a fermented food product produced by inoculating Monascus purpureus into steamed rice [1]. Extracts from red yeast rice are well known for their content of starch, sterols, isoflavones, monounsaturated fatty acids and monacolins. The functions of red yeast rice products include reducing blood serum cholesterol [2], anti-fatigue [3], fighting Alzehimer [4], preventing obesity development [5], and prevention of diabetes development [6]. Monacolins are polyketide derived compounds that has the ability of lowering the blood lipid levels. Increased levels of cholesterol and triglycerides are known to be risk factors for developing coronary artery diseases. Lipid-lowering agents that inhibit HMG coenzyme-A reductase are now prominent among the drugs of choice for treating hypercholesterolemia. Monacolin $\mathrm{k}$ (Figure 1) is a potent inhibitor of HMG-CoA reductase, the rate limiting enzyme in cholesterol biosynthesis and has been demonstrated to be effective in reducing both cholesterol and triglyceride. Fourteen naturally occurring monacolin compounds were identified in red yeast rice (Figure 2), those are monacolin $\mathrm{K}$, monacolin $\mathrm{J}$, monacolin $\mathrm{L}$, monacolin $\mathrm{M}$, monacolin $\mathrm{X}$, and their hydroxy acid form, as well as dehydromonacolin $\mathrm{K}$, dihydromonacolin $\mathrm{L}$, compactin, $3 a$ hydroxy3,5-dihydromonacolin L [7]. Monacolins are a group of statins existing in both lactone forms and hydroxyl acid forms [8]. Monacolin $\mathrm{K}$ is an active pharmaceutical ingredient in the Monascus capsules. Its role is to reduce serum total cholesterol, triglyceride, and LDL cholesterol, increase HDL cholesterol, treat for hyperlipidemia and cardio-cerebrovascular, diseases caused by hyperlipidemia and atherosclerosis. Statins are a novel class of drugs widely used for the treatment of hypercholesterolemia and atherosclerosis commonly known to act as 3-hydroxy-3-methyl glutaryl coenzyme A (HMG-CoA) reductase inhibitors (Figure 3) $[9,10]$. High-performance liquid chromatography (HPLC) shows many advantages in the chemical analysis of herbal medicines and their preparations, such as high sensitivity, reproducibility, good resolution, linearity, the ability to analyze multiple constituents and the ease of automation. Because of the acidity of statin compounds, acidic modifiers are usually used to suppress their ionization and to achieve optimal separation. The modifier used here is di-hydrogen phosphate potassium salt [11]. In this research paper we are using the usefulness of instability of the Monacolin K lactone compound [8-[2-(4-hydroxy-6-oxo-oxan-2-yl) ethyl] -3,7-dimethyl1,2,3,7,8,8a-3,7-dimethyl-1,2,3,7,8,8a-hexahydronaphthalen-1-yl] 2 -methylbutanoate which can be caused by hydrolysis in aqueous media to determine both the lactone and acid form (Figure 4) [12]. The determination of Monacolin K in the capsule of Monascus has great significance for the control of clinical therapy. So, a simple, rapid, and sensitive analytical method for separation and determination of Monacolin K in the capsule of Monascus is of great interest. HPLC has been applied for the qualitative and quantitative analysis of Monacolin $\mathrm{K}$ in the capsule $[11,13]$. The objective of this paper was to quantify the amount of monacolin $\mathrm{k}$ in commercial pharmaceutical preparations containing $M$. purpureus existing in both lactone form and hydroxy acid form using technology of hyphenated HPLC/DAD. The content of monacolin $\mathrm{K}$ in red yeast rice commercial preparation was estimated referenced to standard commercially available monacolin $\mathrm{K}$ lactone form (MKL).

\section{Experimental}

\section{Materials and chemicals}

Capsules of red yeast (Biochol BIO PHARMA EGYPT S.A.E.) were purchased from the Egyptian Drugstores. Reference standard Monacolin $\mathrm{K}$ and $\mathrm{KH}_{2} \mathrm{PO}_{4}$ analysis reagent grade were purchased from sigma. Acetonitrile HPLC grade and Methanol HPLC grade were purchased from Merck.

\section{Equipment (Apparatus and chromatographic conditions)}

HPLC was performed with a Dionex ultimate 3000 isocratic chromatograph equipped with Ultimate 3000 pump, Ultimate 3000

*Corresponding author: Omar MM Sabry, Pharmacognosy Department-Faculty of Pharmacy, Cairo University, Cairo-11562, Egypt, Tel: +201114886724; Fax: +202-23628426; E-mail: omar.sabry@cu.edu.eg

Received September 07, 2015; Accepted October 06, 2015; Published October 10,2015

Citation: Sabry OMM (2015) A New HPLC Method for Analysis of Natural Monacolin K in Red Yeast Rice Pharmaceutical Preparations. J Pharmacogn Nat Prod 1: 106. doi:10.4172/2472-0992.1000106

Copyright: (c) 2015 Sabry OMM. This is an open-access article distributed under the terms of the Creative Commons Attribution License, which permits unrestricted use, distribution, and reproduction in any medium, provided the original author and source are credited. 
column compartment, controlled by Ultimate 3000 autosampler and Ultimate 3000 photodiode array detector (PAD) was used for peak purity test and analysis of compounds. Analysis was performed on a Dionex octadecyl silyl silica gel column $(250 \mathrm{~mm}$ x $4.6 \mathrm{~mm}$ I.D., 5 $\mu \mathrm{m}$ particle size).The mobile phase was Isocratic acetonitrile (A) and $50 \mathrm{mM} \mathrm{KH}_{2} \mathrm{PO}_{4}$ pH 3.5 (B) 60:35. The injection volume was $20 \mu \mathrm{l}$ and the samples were monitored at $237 \mathrm{~nm}$. A constant flow-rate of $1.5 \mathrm{ml} /$ min was used during analysis. HPLC grade solvents and bi-distilled

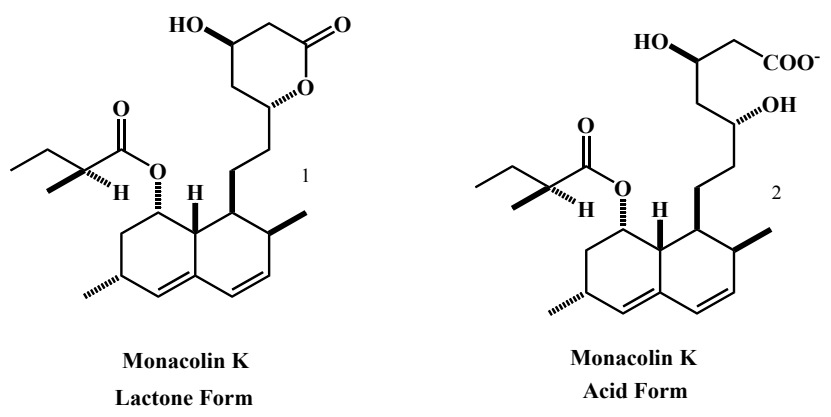

Figure 1: Structure of Monacolin K.

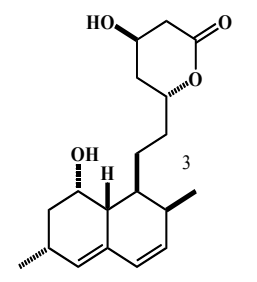

Monacolin J

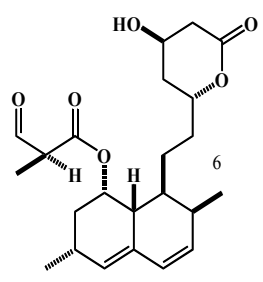

Monacolin X

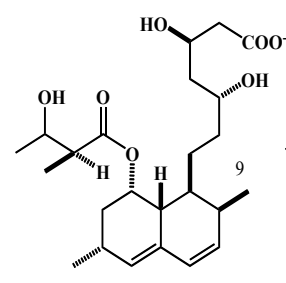

Monacolin M Acid Form

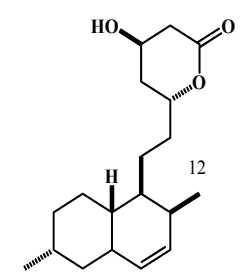

DihydroMonacolin L Acid Form

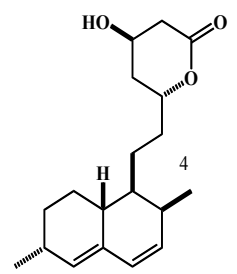

Monacolin L
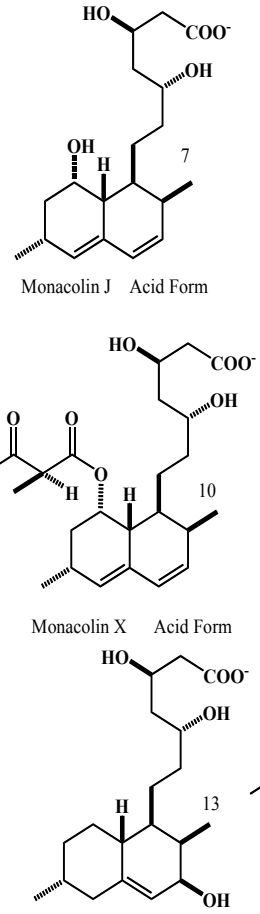

3-hydroxy-3,5-dihydromongentin

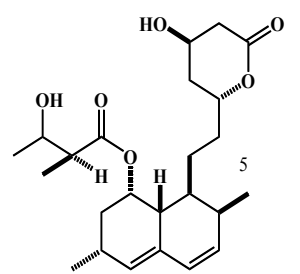

Monacolin M

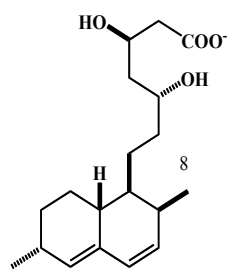

Monacolin L Acid Form

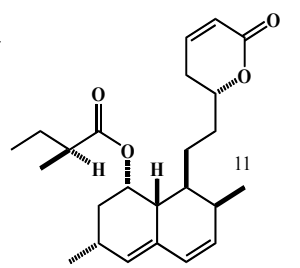

Dehydromonacolin $\mathrm{K}$

$$
\text { HO }
$$

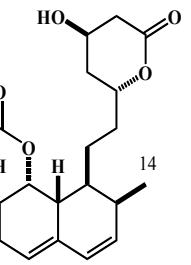

Compactin
Figure 2: Structure of natural monacolins in red yeast rice.

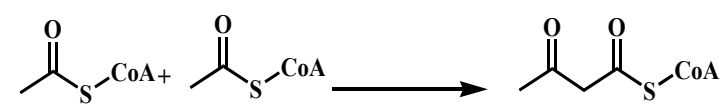

Acetyl CoA Acetyl CoA Acetoacetyl-CoA

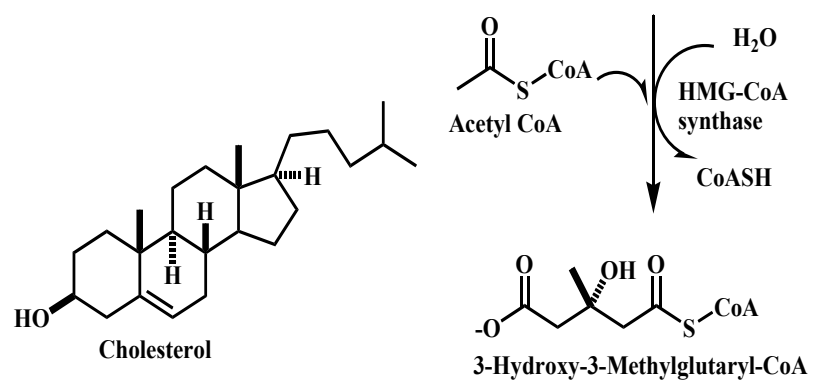

(HMG-CoA)
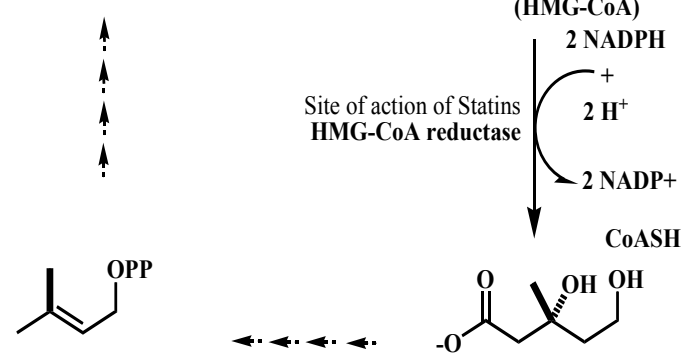

Dimethylallyl pyrophosphate

Mevalonic acid

Figure 3: Mechanism of inhibition of cholesterol biosynthesis by statins.

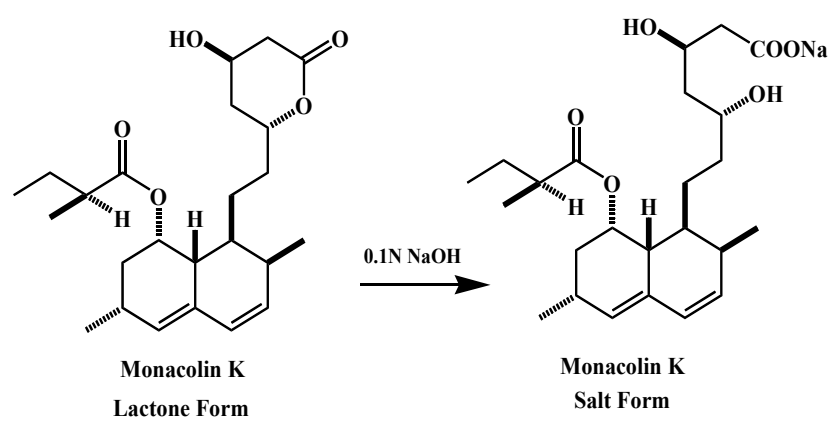

Figure 4: Preparation of Monacolin k acid form.

\section{Calibration Curve 1}

MKL

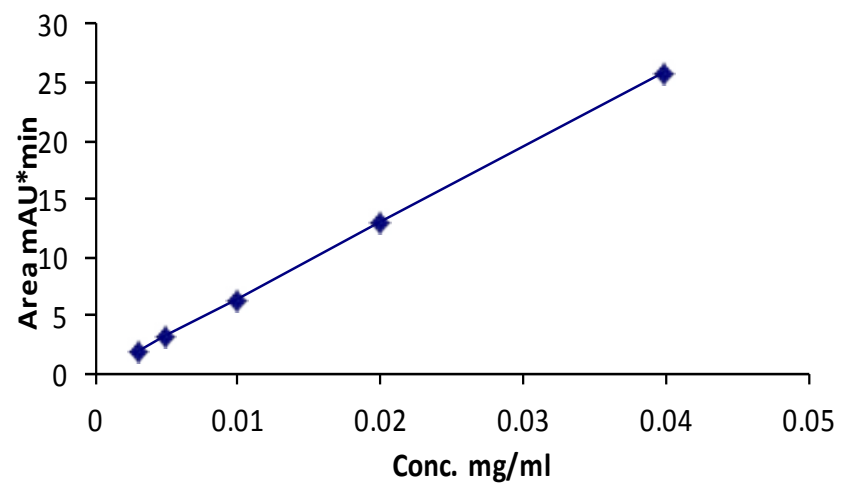

Figure 5: Calibration curve of Monacolin K lactone form. 
water were used in the chromatographic studies. All chromatographic experiments were performed at constant column temperature $40^{\circ} \mathrm{C}$.

\section{Procedure}

\section{Sample preparation}

$150 \mathrm{mg}$ of the red yeast capsule (Biochol Capsule) content were accurately weighed and transferred to $100 \mathrm{ml}$ volumetric flask. $80 \mathrm{ml}$ of mobile phase \{acetonitrile- $50 \mathrm{mM} \mathrm{KH}_{2} \mathrm{PO}_{4} \mathrm{pH} 3.5$ (60:35)\} were added. Mixture was sonicated for 10 minutes to be dissolved. Volume was completed to $100 \mathrm{ml}$ with the mobile phase. Sample was filtered through a $0.45 \mu \mathrm{m}$ syringe membrane filter prior to injection $(20 \mu \mathrm{L})$ into HPLC.

\section{Preparation of standard solutions}

Preparation of standard Monacolin K lactone form (MKL): An accurately weighed amount of lovastatin (Monacolin K) $25 \mathrm{mg}$ (99.5\% purity) was transferred to $100 \mathrm{ml}$ volumetric flask. $70 \mathrm{ml}$ of

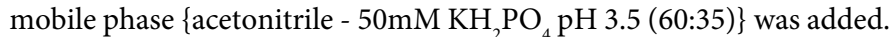
Mixtures were sonicated for 10 minutes to be dissolved. Dilution with mobile phase to $100 \mathrm{ml}$ was carried out to form the parent standard solution.

Standard Solution $5(0.0398 \mathrm{mg} / \mathrm{ml}): 4 \mathrm{ml}$ of the parent standard solution was transferred to a $25 \mathrm{ml}$ volumetric flask; volume was completed and adjusted to $25 \mathrm{ml}$ with the mobile phase acetonitrile- 50 $\mathrm{mM} \mathrm{KH}_{2} \mathrm{PO}_{4} \mathrm{pH} 3.5$ (60:35).

Standard Solution $4(0.0199 \mathrm{mg} / \mathrm{ml}): 2 \mathrm{ml}$ of the parent standard solution was transferred to a $25 \mathrm{ml}$ volumetric flask; volume was completed and adjusted to $25 \mathrm{ml}$ with the mobile phase acetonitrile-50 $\mathrm{mM} \mathrm{KH}_{2} \mathrm{PO}_{4} \mathrm{pH} 3.5$ (60:35).

Standard Solution $3(0.00995 \mathrm{mg} / \mathrm{ml}): 1 \mathrm{ml}$ of the parent standard solution was transferred to a $25 \mathrm{ml}$ volumetric flask; volume was completed and adjusted to $25 \mathrm{ml}$ with the mobile phase acetonitrile-50 $\mathrm{mM} \mathrm{KH}_{2} \mathrm{PO}_{4} \mathrm{pH} 3.5$ (60:35).

Standard Solution $2(0.00497 \mathrm{mg} / \mathrm{ml}): 5 \mathrm{ml}$ of the Standard Solution 3 was transferred to a $10 \mathrm{ml}$ volumetric flask; volume was completed and adjusted to $10 \mathrm{ml}$ with the mobile phase acetonitrile-50 $\mathrm{mM} \mathrm{KH}_{2} \mathrm{PO}_{4} \mathrm{pH} 3.5$ (60:35).

Standard Solution $1(0.00298 \mathrm{mg} / \mathrm{ml}): 3 \mathrm{ml}$ of the Standard Solution 2 was transferred to a $5 \mathrm{ml}$ volumetric flask; volume was completed and adjusted to $5 \mathrm{ml}$ with the mobile phase acetonitrile- $50 \mathrm{mM} \mathrm{KH}_{2} \mathrm{PO}_{4} \mathrm{pH}$ $3.5(60: 35)$.

Preparation of standard Monacolin Kacid form (MKA): Standard Solution $5 \mathrm{~b}(0.0398 \mathrm{mg} / \mathrm{ml}): 2 \mathrm{ml}$ of the Standard Solution 5 were mixed with $2 \mathrm{ml} 0.1 \mathrm{~N} \mathrm{NaOH}$ and kept for $2 \mathrm{~h}$ at $30^{\circ} \mathrm{C}$. The mixture was dried under vacuum, and then dissolved in $2 \mathrm{ml}$ acetonitrile- $50 \mathrm{mM} \mathrm{KH}_{2} \mathrm{PO}_{4}$ $\mathrm{pH} 3.5$ (60:35). The solution was filtered through a $0.45 \mu \mathrm{m}$ membrane syringe filter prior to analysis using HPLC.

Standard Solution $4 \mathrm{~b}(0.0199 \mathrm{mg} / \mathrm{ml}): 2 \mathrm{mls}$ of the Standard Solution 4 were mixed with $2 \mathrm{ml} 0.1 \mathrm{~N} \mathrm{NaOH}$ and kept for $2 \mathrm{~h}$ at $30^{\circ} \mathrm{C}$. The mixture was dried under vacuum, and then dissolved in $2 \mathrm{ml}$ acetonitrile-50 mM KH $\mathrm{PO}_{4} \mathrm{pH} 3.5$ (60:35). The solution was filtered through a $0.45 \mu \mathrm{m}$ membrane syringe filter prior to analysis using HPLC.

Standard Solution 3b $(0.00995 \mathrm{mg} / \mathrm{ml}): 2 \mathrm{mls}$ of the Standard Solution 3 were mixed with $2 \mathrm{ml} 0.1 \mathrm{~N} \mathrm{NaOH}$ and kept for $2 \mathrm{~h}$ at $30^{\circ} \mathrm{C}$.
The mixture was dried under vacuum, and then dissolved in $2 \mathrm{ml}$ acetonitrile-50 mM KH $\mathrm{PO}_{4} \mathrm{pH} 3.5$ (60:35). The solution was filtered through a $0.45 \mu \mathrm{m}$ membrane syringe filter prior to analysis using HPLC.

Standard Solution $2 \mathrm{~b}(0.00497 \mathrm{mg} / \mathrm{ml}): 2 \mathrm{mls}$ of the Standard Solution 2 were mixed with $2 \mathrm{ml} 0.1 \mathrm{~N} \mathrm{NaOH}$ and kept for $2 \mathrm{~h}$ at $30^{\circ} \mathrm{C}$. The mixture was dried under vacuum, and then dissolved in $2 \mathrm{ml}$ acetonitrile-50 mM KH $\mathrm{PO}_{4} \mathrm{pH} 3.5$ (60:35). The solution was filtered through a $0.45 \mu \mathrm{m}$ membrane syringe filter prior to analysis using HPLC.

Standard Solution $1 \mathrm{~b}(0.00298 \mathrm{mg} / \mathrm{ml}): 2 \mathrm{mls}$ of the Standard Solution 1 were mixed with $2 \mathrm{ml} 0.1 \mathrm{~N} \mathrm{NaOH}$ and kept for $2 \mathrm{~h}$ at $30^{\circ} \mathrm{C}$. The mixture was dried under vacuum, and then dissolved in $2 \mathrm{ml}$ acetonitrile- $50 \mathrm{mM} \mathrm{KH}_{2} \mathrm{PO}_{4} \mathrm{pH} 3.5$ (60:35). The solution was filtered through a $0.45 \mu \mathrm{m}$ membrane syringe filter prior to analysis using HPLC.

\section{Calibration curves}

The calibration curve for Monacolin K lactone form (Figure 5) was obtained by plotting the peak areas of Monacolin $\mathrm{K}$ lactone form and Monacolin K acid form versus concentration of Monacolin K lactone form over the range of $0.002985-0.039800 \mathrm{mg} / \mathrm{ml}$. The calibration curve for Monacolin K acid form (Figure 6) was obtained by plotting the peak areas of Monacolin K acid form versus concentration of Monacolin K lactone form (MKL) over the range of $0.002985-0.039800 \mathrm{mg} / \mathrm{ml}$. The data of analysis of the calibration curve are shown in (Table 1 and 2). The recoveries of Monacolin $\mathrm{K}$ lactone form (MKL) and Monacolin $\mathrm{K}$ acid form (MKA) were found to be in the range of $99-101 \%$. The proposed HPLC method was applied to the determination of equivalent amount of Monacolin K lactone form (MKL) in the Biochol capsule dosage form.

\section{Method development}

The procedure was conducted on the liquid chromatography with photodiode array detector was optimized by testing various system conditions. General reverse-phase C18 and ODS columns were used, and several different elution systems were trialed. The resolution and symmetry factors of peaks as monacolin $\mathrm{K}$ with its neighboring peaks were satisfied by using acetonitrile-water system. The symmetry and resolution was increased by lowering the $\mathrm{pH}$ value of elution ( $\mathrm{pH} 3.5)$. Several aqueous solutions such as the phosphoric buffer, acetate acid as well as dilute phosphoric acid and dilute trifluoroacetic acid (TFA) together with an organic phase of methanol or acetonitrile etc. were used for the condition optimization. The results suggested a system composed of acetonitrile - $50 \mathrm{mM} \mathrm{KH}_{2} \mathrm{PO}_{4} \mathrm{pH} 3.5$ (60:35) as an ideal system for the separation of the monacolin compounds. The photodiode array detector was set at $210-350 \mathrm{~nm}$ and the chromatogram detected at $237 \mathrm{~nm}$. The column temperature was set at $40^{\circ} \mathrm{C}$, and the injection volume was $20 \mu \mathrm{l}$. The accuracy of the method was determined by calculating recoveries of Monacolin $\mathrm{K}$ by method of standard additions. Selection of mobile phase was performed based on resolution and theoretical plates obtained for both monacolin $\mathrm{K}$ lactone form and acid form. The mobile phase acetonitrile and 50 mM KH $\mathrm{PO}_{4}(60: 35)$ was found to be satisfactory and gave two wellresolved peaks for Monacolin $\mathrm{K}$ lactone form and Monacolin $\mathrm{K}$ acid form. The retention time for Monacolin K acid form and Monacolin K lactone form were $5.621 \mathrm{~min}$ and $9.07 \mathrm{~min}$, respectively (Figure 7) UV spectra of both the monacolin $\mathrm{K}$ lactone form and monacolin $\mathrm{K}$ acid form showed that both the drugs absorbs appreciably at $237 \mathrm{~nm}$ so, 237 $\mathrm{nm}$ was selected as the detection wavelength in HPLC. 
Citation: Sabry OMM (2015) A New HPLC Method for Analysis of Natural Monacolin K in Red Yeast Rice Pharmaceutical Preparations. J Pharmacogn Nat Prod 1: 106. doi:10.4172/2472-0992.1000106

Page 4 of 4

\begin{tabular}{|c|c|c|c|c|}
\hline $\begin{array}{c}\text { Sample } \\
\text { Name }\end{array}$ & $\begin{array}{c}\text { Conc. } \\
\mathbf{m g} / \mathbf{m l}\end{array}$ & Ret. Time & Area mAU*min & $\begin{array}{c}\text { Height } \\
\text { mAU }\end{array}$ \\
\hline Std 1 & 0.00299 & 9.05 & 2.0008 & 8.25 \\
\hline Std 2 & 0.00498 & 9.04 & 3.2806 & 13.33 \\
\hline Std 3 & 0.00995 & 9.06 & 6.4449 & 26.47 \\
\hline Std 4 & 0.0199 & 9.05 & 13.1608 & 54.56 \\
\hline Std 5 & 0.0398 & 9.06 & 25.8249 & 107.81 \\
\hline
\end{tabular}

Table 1: Concentrations $(\mathrm{mg} / \mathrm{ml})$ and peak areas of standard Monacolin K lactone form.

\begin{tabular}{|c|c|c|c|c|}
\hline $\begin{array}{c}\text { Sample } \\
\text { Name }\end{array}$ & $\begin{array}{c}\text { Conc. } \\
\mathbf{m g} / \mathbf{m l}\end{array}$ & Ret. Time & Area mAU*min & $\begin{array}{c}\text { Height } \\
\text { mAU }\end{array}$ \\
\hline Std $1_{\mathrm{b}}$ & 0.00299 & 5.621 & 2.6677 & 11 \\
\hline Std $2_{\mathrm{b}}$ & 0.00498 & 5.62 & 4.3741 & 17.77 \\
\hline Std 3 & 0.00995 & 5.621 & 8.5932 & 35.29 \\
\hline Std $4_{\mathrm{b}}$ & 0.0199 & 5.621 & 17.5477 & 72.75 \\
\hline Std $5_{\mathrm{b}}$ & 0.0398 & 5.62 & 34.4332 & 142.76 \\
\hline
\end{tabular}

Table 2: Concentrations $(\mathrm{mg} / \mathrm{ml})$ and peak areas of standard Monacolin $\mathrm{K}$ acid form.

\begin{tabular}{|c|c|c|c|}
\hline Peak No. & Compound & Ret. Time & $\begin{array}{c}\text { Conc. } \\
\mathbf{m g} / \mathbf{m l}\end{array}$ \\
\hline 1 & Monacolin K acid form & 5.621 & 0.0027 \\
\hline 2 & Monacolin K lactone form & 9.07 & 0.0035 \\
\hline
\end{tabular}

Table 3: Concentration of monacolin $\mathrm{K}$ in the sample prepared.

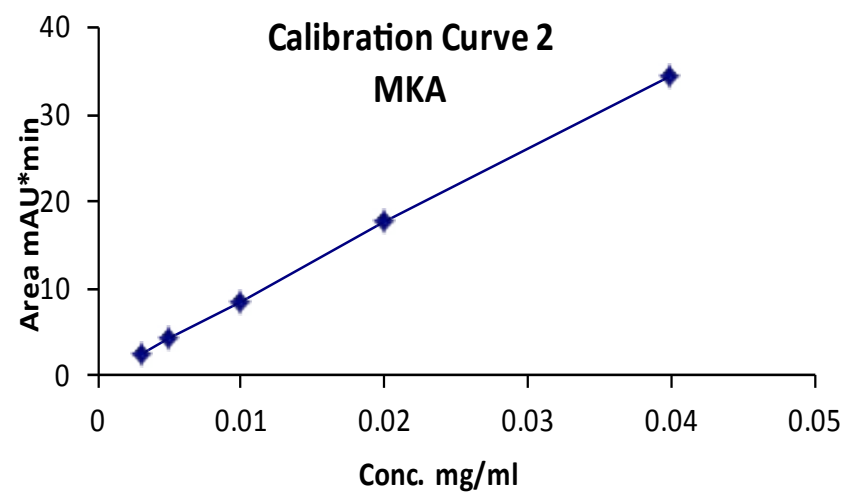

Figure 6: Calibration curve of Monacolin $\mathrm{K}$ acid form

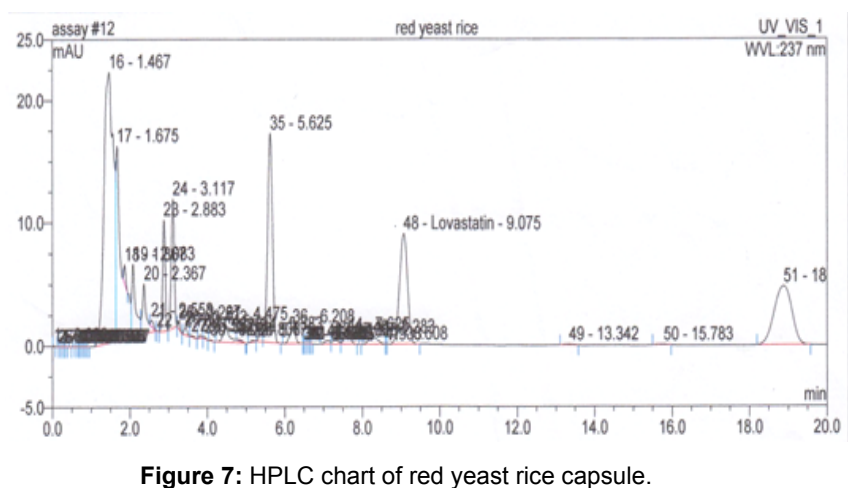

\section{Results}

From the constructed standard calibration curve: Concentrations of Monacolin $\mathrm{K}$ lactone form and Monacolin $\mathrm{K}$ acid form were found to be $0.0035 \mathrm{mg} / \mathrm{ml}$ and $0.0027 \mathrm{mg} / \mathrm{ml}$. The total concentration of Monacolin K was found to be $0.0062 \mathrm{mg} / \mathrm{ml}$. Monacolin $\mathrm{K}$ in $100 \mathrm{ml}$ sample solution ( $150 \mathrm{mg}$ powdered red yeast) is $0.62 \mathrm{mg}$. Concentration of monacolin $\mathrm{K}$ in $600 \mathrm{mg}$ red yeast capsule (Biochol) is $2.48 \mathrm{mg} /$ capsule (103.3\% of the corresponding labeled amount) (Table 3 ).

\section{Discussion}

The results of the experiment demonstrate that the proposed HPLC method is suitable for the determination of Monacolin $\mathrm{K}$ content in the commercial Red yeast rice capsule. In addition, the method is reliable, simple and sensitive.

\section{Conclusion}

This work is the first work that can show how to determine both Monacolin $\mathrm{K}$ lactone form (MKL) and monacolin $\mathrm{k}$ acid form (MKA) in the complex extract of the Red Yeast Rice Pharmaceutical Preparations by the powerful HPLC technique.

\section{References}

1. Shi YC, Pan TM (2011) Beneficial effects of Monascus purpureus NTU 568-fermented products: a review. Appl Microbiol Biotechnol 90: 1207-1217.

2. Lee CL, Tsai TY, Wang JJ, Pan TM (2006) In vivo hypolipidemic effects and safety of low dosage Monascus powder in a hamster model of hyperlipidemia. Appl Microbiol Biotechnol 70: 533-540.

3. Wang JJ, Shieh MJ, Kuo SL, Lee CL, Pan TM (2006) Effect of red mold rice on antifatigue and exercise-related changes in lipid peroxidation in endurance exercise. Appl Microbiol Biotechnol 70: 247-253.

4. Lee CL, Kuo TF, Wu CL, Wang JJ, Pan TM (2010) Red mold rice promotes neuroprotective SAPPalpha secretion instead of Alzheimer's risk factors and amyloid beta expression in hyperlipidemic Abeta40-infused rats. J Agric Food Chem 58: 2230-2238.

5. Jou PC, Ho BY, Hsu YW, Pan TM (2010) The effect of Monascus secondary polyketide metabolites, monascin and ankaflavin, on adipogenesis and lipolysis activity in 3T3-L1. J Agric Food Chem 58: 12703-12709.

6. Shi YC, Pan TM (2010) Characterization of a Multifunctional Monascus Isolate NTU 568 with High Azaphilone Pigments Production. Food Biotechnol 24: 349363.

7. Li YG, Zhang F, Wang ZT, Hu ZB (2004) Identification and chemical profiling of monacolins in red yeast rice using high-performance liquid chromatography with photodiode array detector and mass spectrometry. J Pharm Biomed Anal 35: 1101-1112.

8. Juzlova P, Martinkova L, Kren V (1996) Secondary metabolites of the fungus Monascus: a review. J Ind Microbiol 16: 163-170.

9. Budavari S, O'neil M, Smith A, Heckelman P, Obenchain J (1996) The Merck Index: Encyclopedia of Chemicals, Drugs and Biologicals (Merck Index). (12th edn) Merck \& Co Inc, USA Pp: 1741.

10. Gennaro AR (2000) Remington: The Science and Practice of Pharmacy. (20th edn) Lippincott Williams \& Wilkins, USA.

11. Huang HN, Hua YY, Bao GR, Xie LH (2006) The quantification of monacolin $\mathrm{k}$ in some red yeast rice from fujian province and the comparison of the other products. Chem Pharm Bull 54: 687-689.

12. Miao XS, Metcalfe CD (2003) Determination of cholesterol-lowering statin drugs in aqueous samples using liquid chromatography-electrospray ionization tandem mass spectrometry. J Chromatogr A 23: 133-141.

13. Zhang XQ, Chou FR (1997) J Chin Med 22: 222-224 